\section{忘却係数付き逐次最小二乗法に よる建物動特性の地震時変化の 評価}

\title{
BUILDING DYNAMIC PROPERTY CHANGE UNDER AN EARTHQUAKE EVALUATED BY THE FORGETTING FACTOR RECURSIVE LEAST SQUARES METHOD
}

池田芳樹 ——

キーワード :

システム同定, 損傷検知, 忘却係数付き逐次最小二乗法, ARX モデル, 実大鉄骨造建物，震動台実験

Keywords:

System identification, Damage detection, Forgetting factor recursive LSM, ARX model, Full-scale steel building, Shaking table test

1. はじめに

地震直後の建物被荻度判定を迅速に進める手段の一つとして，振 動計測に基づいて建物動特性を把握する技術が求められている. し かしながら, システム同定や損傷検知といった逆問題で複雑な数理 モデルを扱うことは難しく, 層剛性や部材損傷の判定には多数の計 測点が必要となる。さらに，振動が大きいほど建物は高い非線形性 を示すが，特定の同定法や損傷検知法で実建物の多様な非線形性を 迅速に評価できるほど, 研究開発は進展していない，同定法の適用 性と汎用性を考慮すれば，建物動特性の変化を等価線形的に評価す る手法は，現実的な被災度判定法として選択の一つと考えられる.

本報告は，忘却係数付き逐次最小二乗法によって建物を 1 入力 1 出力系 ARX モデルとして同定し, 低次振動モードの振動数と減衰 の時間変化を把握する方法を検証している. 1 入力 1 出力系は, 建 物の地震被災度を把握する最低条件であり，振動計測に関する費用 軽減を意味する。手法の検証には, 独立行政法人・防災科学技術研 究所の実大 3 次元震動破壊実験施設が 2007 年 9 月に実施し, 実験デ ータを公開している, 実大 4 層鉄骨造建物の震動台実験を用いた ${ }^{1)}$.

忘却係数付き逐次最小二乗法は，同定時刻に近いデータほど重要 視する評価関数を設定しており ${ }^{2)}$, パラメータが変化する非線形シ ステムへの適用性がある。この最小二乗法は 7 層鉄筋コンクリート 造建物の地震記録に適用され, 建物動特性の時間変化が推定された が, 推定結果と実現象との対応には踏夕込まれておらず, 非線形挙 動を示す建物への適用性を判断する情報が不足していた ${ }^{3)}$. その後, 損傷を模擬する装置を各層に組み入れた 3 層鉄骨造試験体の震動台 実験に適用され，初期值と忘却係数の影響および固有振動数の低下 と剛性低下の関係が確認された ${ }^{4)}$. 元来逐次型であるカルマンフィ ルタに忘却係数を組み入れた同定法も，1 自由度系モデルによる数 值解析で固有振動数の変化への追従性の高さが確認された ${ }^{5)}$. 文献 4 と 5 は固有振動数の変化に着目して手法の有効性を検討しており, さらに減衰の変化に着目した検討を加えれば，本手法の建物被災度 判定への有効性をより多面的に理解することができる. また, 忘却

\section{Yoshiki IKEDA —— $*$}

This paper reports a simple damage detection method applied to a building under an earthquake excitation. The structure is modeled as a single-input-single-output ARX model, which means only two measurements in each direction. The model parameters are linearly identified by the forgetting factor recursive least-squares algorithm. When the structure is damaged, its natural frequencies decrease and the corresponding damping ratios increase. The identification can understand the time of damage occurrence directly and the damage level indirectly. The applicability is verified by shaking table tests of a fullscale 4-story steel building at the E-Defense.

係数付き一括最小二乗法は免震建物の地震記録に適用され, 固有振 動数とモード減衰の時間変化が推定された ${ }^{6,7)}$ が，変化の妥当性は 直接検証されておらず，モード特性の振幅依存性の報告にとどまっ ている. 本報告は, 同定した固有振動数と減衰を異なる評価法によ る結果と比較して，同定法の適用性を定量的に評価している.

\section{2. 忘却係数付き逐次最小二乗法}

建物を 1 入力 1 出力系 $\mathrm{ARX}$ モデルで表現し, そのパラメータを 以下に示す忘却係数付き逐次最小二乗法で推定した.

$$
\begin{gathered}
\text { 評価関数 } \quad J_{N}=\sum_{k=1}^{N} \rho^{N-k}\left(y_{k}-z_{k}^{T} \theta\right)^{2} \\
\text { 推定值 } \quad \hat{\theta}_{N}=\left(\sum_{k=1}^{N} \rho^{N-k} z_{k} z_{k}{ }^{T}\right)^{-1} \sum_{k=1}^{N} \rho^{N-k} z_{k} y_{k} \\
\text { アルゴリズム } \quad \hat{\theta}_{N}=\hat{\theta}_{N-1}+\frac{P_{N-1} z_{N}}{\rho+z_{N}{ }^{T} P_{N-1} z_{N}}\left(y_{N}-z_{N}{ }^{T} \hat{\theta}_{N-1}\right) \\
P_{N}=\frac{1}{\rho}\left(P_{N-1}-\frac{P_{N-1} z_{N} z_{N}{ }^{T} P_{N-1}}{\rho+z_{N}{ }^{T} P_{N-1} z_{N}}\right)
\end{gathered}
$$

ここに， $y_{k}$ は離散時刻 $k$ の出力， $z_{k}$ は観測から構成される回帰べ クトル， $\theta_{N}$ は時刻 $N$ のパラメータベクトル， $\rho(0<\rho \leq 1)$ は忘却係 数と呼ばれる重み係数, $P_{N}$ は時刻 $N$ までの推定誤差の共分散行列で ある. 忘却係数の最適值を求める一般的方法はないが, 0.95 から 0.999 の範囲で選択される場合が多い ${ }^{3)-8)} .1 .0$ は重みがないことを 意味する. 式(1)で新しい観測に古い観測よりも重みを付け, 式 (3) で直前の推定值を更新寸るため, 非線形システムに対応できると考 えられる. 実際には, ARX モデルのパラメータから評価したモード の固有振動数と減衰比 ${ }^{9)}$ を用いて，特性変化を評価した。

\section{3. 検証に利用した震動台実験}

対象建物は 4 階建の純ラーメン構造で，柱は角型鋼管，梁は H 型 鋼, 柱梁接合部は通しダイアフラム形式, 柱脚は露出形式である. 1 階に床はなく, 2〜4 階はデッキプレートに鉄筋コンクリートスラブ を打設した合成デッキスラブになっている. 架構は短辺方向が 1 ス 
パン $6 \mathrm{~m}$, 長辺方向が 2 スパン $10 \mathrm{~m}$ で, 高さは $14.4 \mathrm{~m}$ である. ALC 版の外壁が, 長辺方向の 1 構面を除く 3 構面に取り付けられている.

1995 年兵庫県南部地震 JR 鷹取駅の記録による震動台実験では, 記録の NS 成分は長辺方向に, EW 成分は建物短辺方向に, UD 成分 は上下方向に入力された．加振レベルは原波に対する倍率で表現さ れ，原波入力 $(100 \%$ 加振）では震動台上の最大加速度は水平 2 方向 とも約 $8.5 \mathrm{~m} / \mathrm{s}^{2}$ であった. 本検討では, 加振直前の微動部分を除いて 表 1 に示す実験データを用いた.

紙面の制約から，本報告は長辺方向の同定結果を示す，長辺方向 の層間変形角は，20\%加振時に $0.0053 \mathrm{rad}$ で $1 / 200$ を超えていた．層 間変位一層せん断力の関係から 1 ～3 層で履歴ループを描く非線形 性が若干認められたが，鋼部材の歪は弾性範囲内にあったため, こ の非線形性は非構造部材などの影響と報告されている ${ }^{10)}$. 40\%以上 の加振では, 構造部材は塑性域の挙動を示していた ${ }^{11)}$. 40\%加振時 には長辺方向の最大層間変形角は 1 層で最大になり，1/100を僅か に超えていた。 $60 \%$ 加振では 1 層と 2 層でさらに塑性化が進み, 最 大層間変形角は $40 \%$ 加振と同じ層で生じていた，その時の長辺方向 1 層の最大変形角は約 $1 / 50$ である. $60 \%$ 加振後には, 1 層柱脚の僅 かな局部座屈および 2 階と 3 階の床スラブの亀裂も確認された. $100 \%$ 加振で 1 層柱の局部座屈に伴う耐力低下があり, 公開データの 18 秒以降で倒壊に至った ${ }^{12)}$.

同定の入力は震動台中央の長辺方向加速度, 出力は屋上階中央の 長辺方向加速度とした．実験の計測サンプリング振動数は $1000 \mathrm{~Hz}$ であるが，10 離散時刻ごとに選択して $100 \mathrm{~Hz}$ にして用いた。

表 1 同定に利用した JR 鷹取波による振動台実験

\begin{tabular}{ccc}
\hline 試験番号 & 加振レベル & 同定開始時刻 \\
\hline $2007-0920-010-1 \mathrm{M}$ & $5 \%$ & $15.0 \mathrm{~s}$ \\
$2007-0924-014-1 \mathrm{M}$ & $20 \%$ & $12.0 \mathrm{~s}$ \\
$2007-0925-019-1 \mathrm{M}$ & $40 \%$ & $12.0 \mathrm{~s}$ \\
$2007-0925-021-1 \mathrm{M}$ & $60 \%$ & $12.0 \mathrm{~s}$ \\
$2007-0927-013-1 \mathrm{M}$ & $100 \%$ & $12.0 \mathrm{~s}$ \\
\hline
\end{tabular}

\section{4. 同定方針}

一般に，パラメータ推定とモデル次数の決定は互いに独立ではな 〈 ${ }^{2)}{ }^{13)}$, 最近ではベイズモデルに基づく ARX モデルの次数決定法 も提案されている ${ }^{14)}$. 実建物の振動記録は多くのモード成分や物理 的意味が見つけにくい信号を含むため，そのまま同定法を適用する とモデル次数がかなり高くなることが知られている.したがって， 最適なモデル次数を得るためには試行錯誤が必要で，これは計算労 力の増加を意味する.また，ARX モデルで複数モードを同時に同定 すると，振動数ごとに異なる重みが評価誤差に間接的に与えられる 性質がある ${ }^{8)}$. 本検討では，非線形性を有する建物を等価線形的に モード同定しており，㛜密なモデル次数の決定が重要な意味をもち にくい，そこで実用性に配慮して，同定前にバンドパスフィルタで モード成分を抽出する信号処理をした上で, ARX モデル次数を仮定 した.すなわち,パラメータ推定をモデル次数決定から独立させた. 1 次モードの同定では $0.5 \sim 2.0 \mathrm{~Hz}$ の成分を通すフィルタを, 2 次モ 一ドの同定では 3.0〜 $5.0 \mathrm{~Hz}$ の成分を通すフィルタを用いた. 各モー ド同定で，モデル次数は自己回帰項で 2 , 外生入力項で 2 とした. 外生入力項は, 直達項 (0 次遅れの項) を含んでいる.

$\theta_{N}$ の初期值は, $5 \%$ 加振で $\rho=1.0$ の場合の同定開始 40 秒後の值 とした。これは，大地震の経験前に小地震による同定が実施されて
いることを意味する. 1 次モード同定の初期パラメータは，固有振 動数 $1.34 \mathrm{~Hz}$, 減衰比 $4.2 \%$, 刺激関数 1.16 に対応している. $P_{0}$ は対 角行列とし，その值が大きいとパラメータ収束が速くなるため ${ }^{13)}$, 対角成分を $1.0 \times 10^{4}$ とした．加速度の単位は $\mathrm{m} / \mathrm{s}^{2}$ である。

\section{5. 同定結果}

忘却係数を $1.00 ， 0.98$ および 0.95 の 3 つに設定して，40\%加振時 に 1 次モードを同定した結果を図 1 に示す。眓 2 は, 図 1 の同定に 対応する入力加速度と出力加速度である (公開データ). 振動数, 減 衰とも忘却係数 1.00 では一定值に収束する傾向を示し, 係数が小さ くなるほど時間変化が大きくなっている，減衰比には負となる時間 帯がある．減衰は振動数に比較して変化が大きく，モード同定の性 質と整合している.19秒付近に振動数の低下と減衰の増加があり，

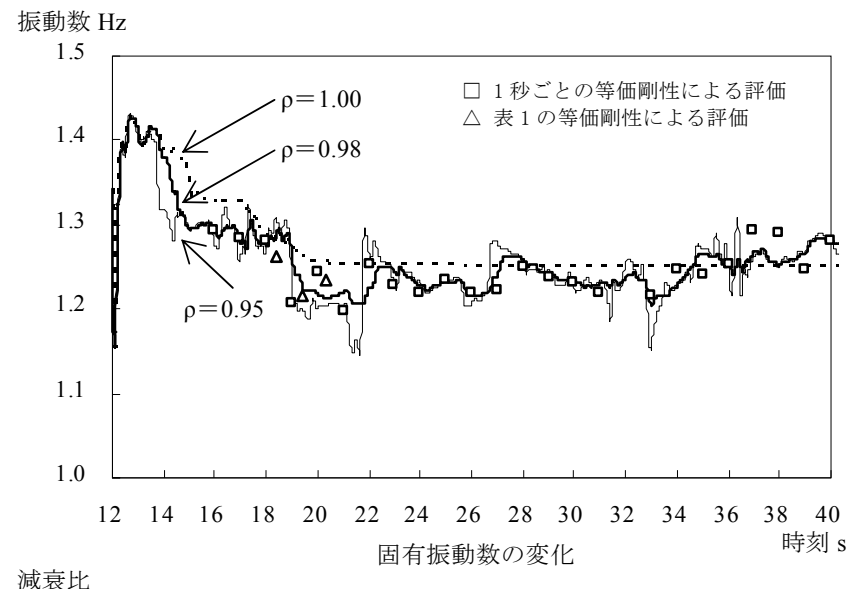

減衰比

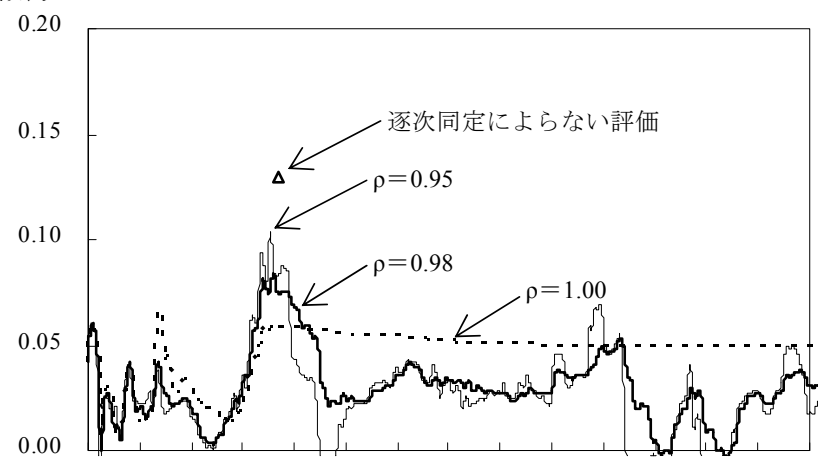

$\begin{array}{lllllllllllllll}12 & 14 & 16 & 18 & 20 & 22 & 24 & 26 & 28 & 30 & 32 & 34 & 36 & 38 & 40\end{array}$ 減衰比の変化

図 $140 \%$ 加振時の建物の 1 次モードの変化

時刻 $\mathrm{s}$

加速度 $\mathrm{cm} / \mathrm{s}^{2}$



加速度 $\mathrm{cm} / \mathrm{s}^{2}$ 出力（屋上階中央）

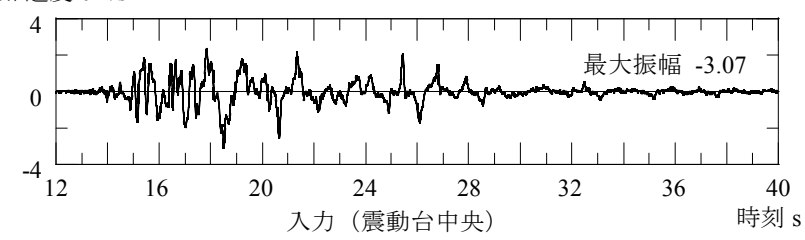

図 $240 \%$ 加振時の同定に用いた入力と出力（長辺方向） 
建物振動が大きい時刻に対応している. 図 3 は $60 \%$ 加振時の変化で あり, 忘却係数と同定結果の変化幅の関係や 19 秒付近の同定值の急 変は, $40 \%$ 加振と同様の傾向を示している.

振動数評価の妥当性を検証するために, 層間変位一層せん断力の 関係から最小二乗法によって 1 秒ごとに層の等価剛性を算定し，4 質点 1 本棒せん断振動型モデルを介して 1 次固有振動数を計算した. 図 1 と図 3 の上図には，その值を評価した最終時刻に口で示してい る. 層せん断力は, それより上の階の平面中央における計測加速度 と重量 ${ }^{10)}$ の積を合算して求め, 層間変位も平面中央付近の計測を用 いた。 15 秒以前および 32 秒では, 層間変位一層せん断力関係の乱 れから剛性評価が難しかったため, 振動数を図示していない。大き さと形状の異なる履歴ループの断片が混在した時間帯では，等価剛 性の評価誤差が大きくなる可能性がある，そこで，19秒前後では各 層の履歴形状が整うような時間帯で等価剛性を再評価し（表 2)，そ の值を図 1 と図 3 の上図に $\triangle$ として加えた. 同定結果は $\triangle$ に対して やや適合性が高く, 時間全体では等価剛性から評価した振動数の変 化によく対応している.

1 次モードの減衰は, 表 2 の時間帯 B で評価した。粘性減衰は, Bouc-Wen モデルで同定した層の粘性減衰 ${ }^{15)}$ 之時間帯 B の等価剛性 から， 4 質点 1 本棒せん断振動型モデルの固有值解析を介して求め た. $40 \%$ 加振で $4.0 \%, 60 \%$ 加振で $4.6 \%$ でる. 履歴減衰は, 時間帯 B で建物が共振状態に近いと判断して, 図 4 の履歴ループから求め た. 1 次モード減衰を算定する目的で, 図 4 は透過振動数 $0.5 \sim 2.0 \mathrm{~Hz}$ のバンドパスフィルタに通されている. 各層のポテンシャルエネル ギは, 等価剛性 $k$ と変位の最大片振幅の平均 $a$ から $k a^{2} / 2$ で評価した (表 3). 1 次モードの履歴減衰は, $40 \%$ 加振で $9.0 \%, 60 \%$ 加振で $13.2 \%$ である. 図 1 と図 3 の下図には, 粘性減衰と履歴減衰の和を $\triangle$ で図 示している，調和加振時ではない履歴曲線から等価粘性減衰を求め る近似を考えれば, 同定結果と評価值は対応していると考えられる.

図 5 は, $\rho=0.98$ の場合で 1 次モードの固有振動数と減衰比の変 化を 4 つの震動台実験で比較している．加振レベルが大きくなるほ ど固有振動数は小さくなる傾向にあるが，倒壊に至った $100 \%$ 加振 では同定結果の変化が著しく大きく, 他の加振とは明らかに傾向が 異なっている. 同一の加振では 19〜22 秒で固有振動数が低下寸る傾 向にあり $40 \%$ と $60 \%$ の加振の 19 秒付近で塑性域に入っていること に対応している. $20 \%$ 加振では, 低下した固有振動数が 30 秒以降に 戻る現象が見られる. 減衰比では, 19〜20 秒と 32 秒前後で加振レ ベルによる差異が明瞭になっており，その時間帯では加振レベルが 大きくなるほど減衰比が大きくなる傾向にある. 21〜30 秒の時間帯 では，加振レベルによる減衰比の違いはあまり見られない，減衰比 の変化は, 層間変位と層せん断力による履歴ループの大きさと対応 が見られた。 $100 \%$ 加振で倒壊直前の 19 秒で, 固有振動数と減衰比 の急激な変化が見られるが, 実現象との関係が見出せず, $100 \%$ 加振 に対する手法の適用性はないと考えている.

図 6 は, 2 次モードで加振レベルの違いを比較している. 2 次振動 数も 1 次振動数と同様に加振レベルが大きくなるほど小さくなる傾 向にある.減衰比の大小関係は 22〜28 秒の時間帯で加振レベルとの 関係が認められるものの, 継続時間全体では加振レベルとの関係は それほど明確ではない。この適用例では，2 次モードの減衰比の変 化を損傷と関連付けることは難しい.
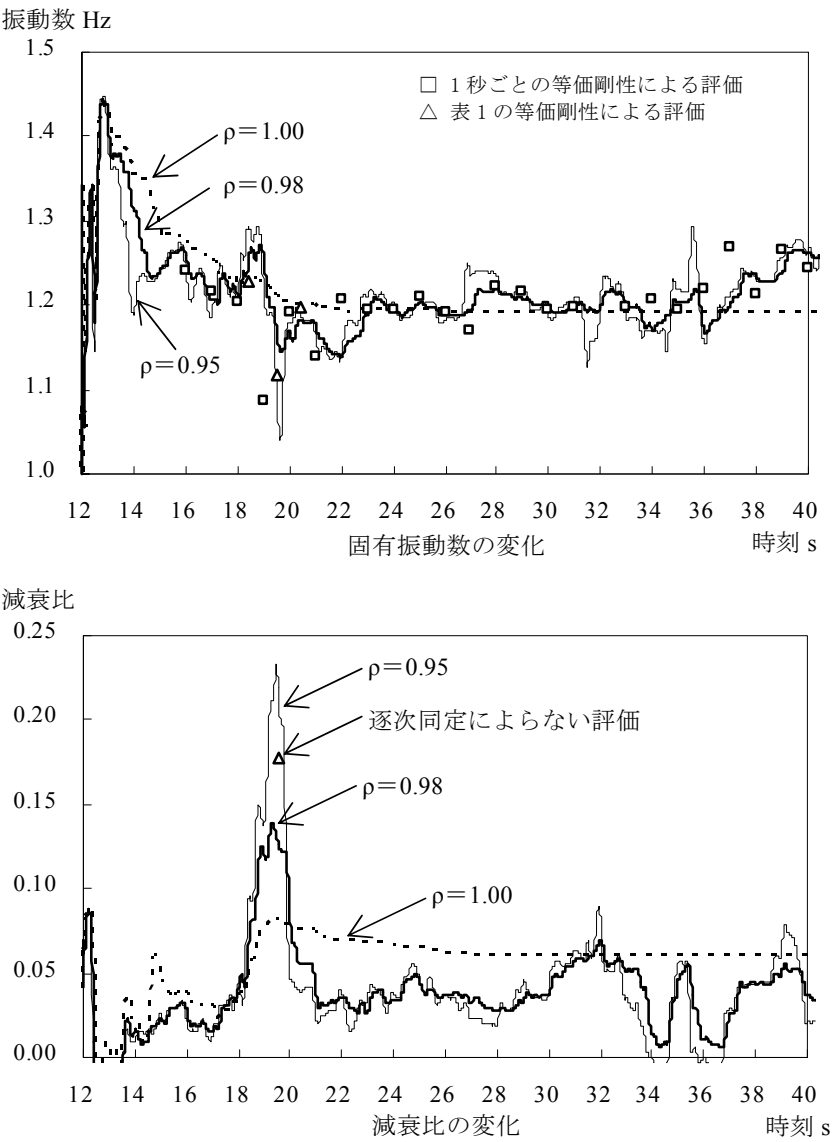

図 $360 \%$ 加振時の建物の 1 次モードの変化

表 2 各層の履歴形状が整うような時間帯における等価剛性の評価

\begin{tabular}{ccrcccc}
\hline \multirow{2}{*}{ 加振レベル } & \multirow{2}{*}{ 評価時間帯 $\mathrm{s}$} & \multicolumn{4}{c}{ 等価剛性 $\mathrm{kN} / \mathrm{mm}$} \\
\cline { 3 - 7 } & & & 1 層 & 2 層 & 3 層 & 4 層 \\
\hline \multirow{2}{*}{$40 \%$} & $\mathrm{~A}$ & $17.72-18.38$ & 32.19 & 28.23 & 26.28 & 24.17 \\
& $\mathrm{~B}$ & $18.38-19.42$ & 28.16 & 26.85 & 25.84 & 23.66 \\
& $\mathrm{C}$ & $19.42-20.33$ & 31.22 & 26.79 & 24.88 & 23.28 \\
\hline \multirow{2}{*}{$60 \%$} & $\mathrm{~A}$ & $17.75-18.40$ & 30.21 & 26.58 & 25.07 & 23.72 \\
& $\mathrm{~B}$ & $18.40-19.54$ & 21.98 & 22.97 & 23.73 & 22.69 \\
& $\mathrm{C}$ & $19.54-20.42$ & 28.81 & 25.37 & 23.79 & 22.65 \\
\hline
\end{tabular}

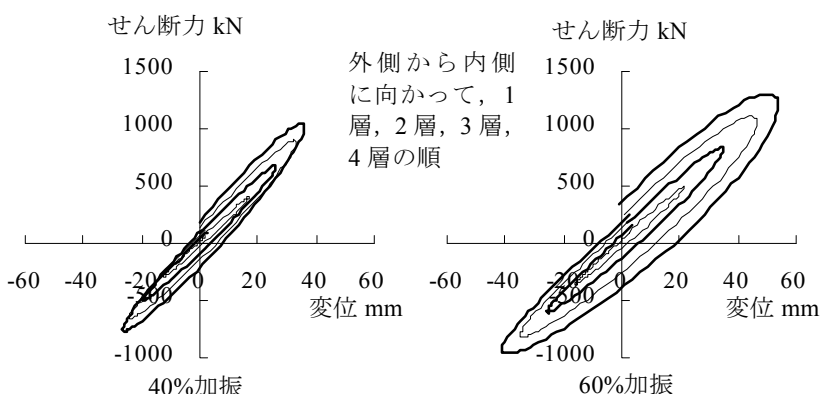

図 4 表 2 時間帯 $\mathrm{B}$ におけるフィルタ処理後の層間変位一層せん断力関係

表 3 表 2 の時間帯 B で履歴減衰の評価に用いた諸定数

\begin{tabular}{cccccc}
\hline 加振レベル & 評価項目 & 1 層 & 2 層 & 3 層 & 4 層 \\
\hline \multirow{2}{*}{$40 \%$} & 履歴ループ面積 $\mathrm{kNmm}$ & 18870 & 12450 & 5800 & 1590 \\
& ポテンシャルエネルギ $\mathrm{kNmm}$ & 13880 & 11060 & 6730 & 2630 \\
& 減衰定数\% & 10.8 & 9.0 & 6.9 & 4.8 \\
\hline \multirow{2}{*}{$60 \%$} & 履歴ループ面積 $\mathrm{kNmm}$ & 53360 & 30420 & 11610 & 2590 \\
& ポテンシャルエネルギ $\mathrm{kNmm}$ & 25620 & 18900 & 10750 & 4000 \\
& 減衰定数\% & 16.6 & 12.8 & 8.6 & 5.1 \\
\hline
\end{tabular}




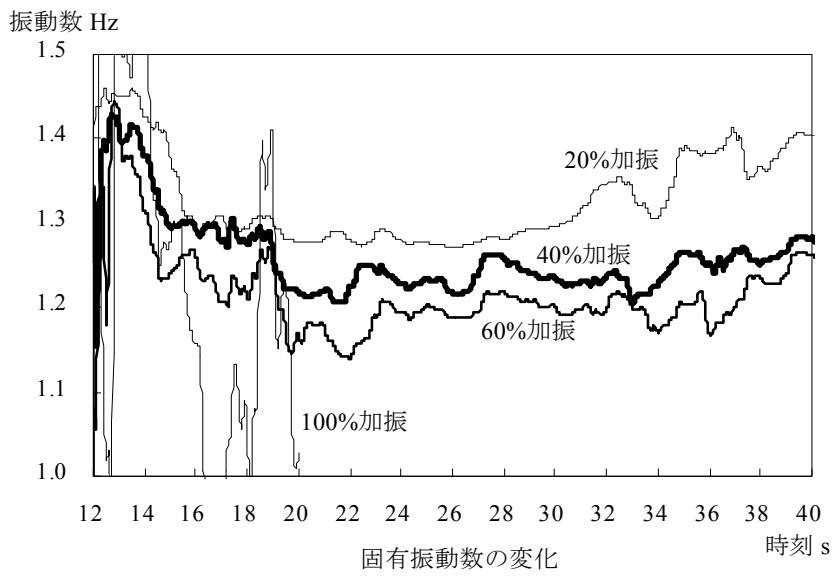

減衰比

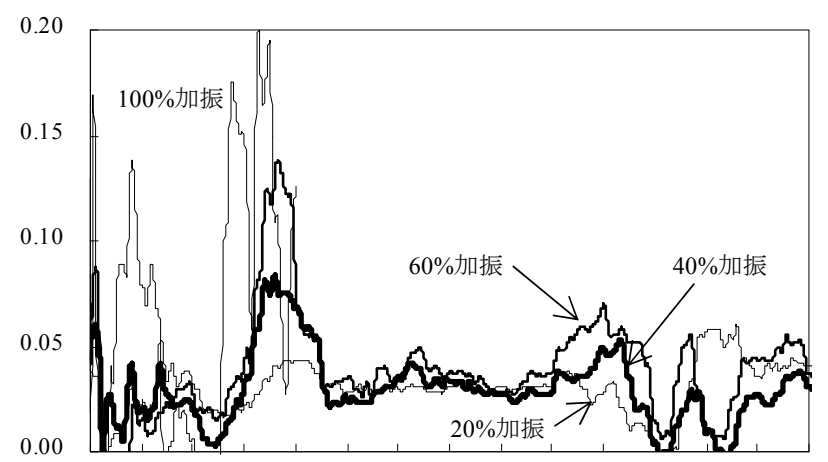

$\begin{array}{lllllllllllllll}12 & 14 & 16 & 18 & 20 & 22 & 24 & 26 & 28 & 30 & 32 & 34 & 36 & 38 & 40\end{array}$ 減衰比の変化

図 51 次モードの 4 つの震動台実験による比較（忘却係数 0.98） 振動数 $\mathrm{Hz}$

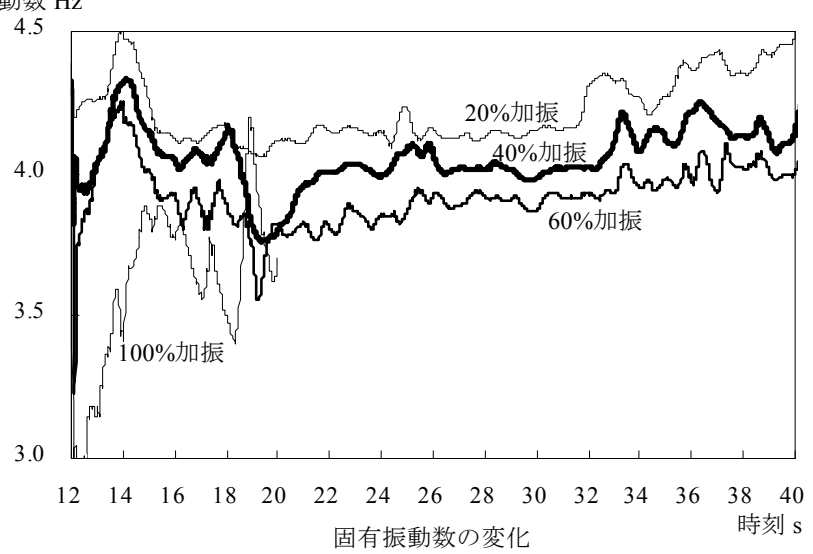

減衰比



図 62 次モードの 4 つの震動台実験による比較（忘却係数 0.98）

\section{6. まとめ}

忘却係数付き逐次最小二乗法に基づいて建物を 1 入力 1 出力系 ARX モデルとして同定し, 低次振動モードの振動数と減衰の時間変 化から簡易に建物被災度を把握する方法を，実大 4 層鉄骨造建物の 震動台実験データで検証した，適用例では，等価線形評価した 1 次 と 2 次モードの固有振動数が低くなり，1 次モードの減衰比が高く なる時刻で，層間変位一層せん断力の関係が大きな履歴ループを描 いていた． 1 次固有振動数の変化は，履歴ループから最小二乗法近 似した等価剛性を用いて計算した固有振動数の変化とよく対応して いた，建物が最も大きな履歴ループを描く時間帯では，同定した 1 次モード減衰比も, 実験から近似評価した值との対応が見られた. 2 次モードでは，固有振動数の変化は損傷と関係していたが，減衰比 には明瞭な対応は認められなかった。また, 建物が倒壊した実験で は，手法の適用性は認められなかった。

本手法によって損傷位置の特定はできないが，ねじれ振動が小さ く水平 2 方向が独立に扱える場合には, 1 入力 1 出力系の限られた 観測でも建物損傷の発生時刻と大まかな地震被荻度を把握できる可 能性がある.

参考文献

1）（独）防災科学技術研究所データ公開システム「ASEBI」より課題「鉄骨 造建物実験研究 完全崩壊再現実験」(https://www.edgrid.jp/data/0703)

2) 中溝高好 : 信号解析とシステム同定, コロナ社, 1988.3

3) Loh, C.-H. and Lin H.-M.: Application of Off-line and On-line Identification Techniques to Building Seismic Response Data, Earthquake Engineering \& Structural Dynamics, Vol.25, No.3, pp.269-290, 1996.3

4) 濱本卓司, 森田高市, 相馬澄子 : 逐次最小二乗法による多層建築物の地震 損傷追跡, 日本建築学会構造系論文集, 第 603 号, pp.39-46, 2006.5

5) 桐田史生ほか 3 名:建築物の地震損傷検知のための適応回帰型システム同 定，日本建築学会構造系論文集，第 619 号，pp.65-72，2007.9

6) 中村充, 竹脇出 : 地震観測結果に基づく免震建物モーダルパラメータの時 変性評価, 日本建築学会大会学術講演梗概集 (近畿), B-2 構造 II, pp.675-676, 2005.9

7) Takewaki I. and Nakamura M: Temporal Variation of Model Properties of a Base-isolated Building during an Earthquake, Journal of Zhejiang University-SCIENCE A, Vol.11, No.1, pp.1-8, 2010

8) 足立修一 : ユーザのためのシステム同定理論, 計測自動制御学会編, コロ ナ社, 1993.7

9) Safak E.: Adaptive Modeling, Identification, and Control of Dynamic Structural System. 1: Theory, Journal of Engineering Mechanics, Vol.115, No.11, pp. 2386-2405, 1989.11

10) 吹田啓一郎ほか 5 名:震動台実験の概要と弾性応答特性一実大 4 層鉄骨造 建物の完全崩壊実験 その $1-$, 日本建築学会構造系論文集, 第 74 巻, 第 635 号, pp.157-166, 2009.1

11) 山田哲ほか 3 名:振動台実験における弾塑性応答特性と崩壊メカニズムの 形成一実大 4 層鉄骨造建物の完全崩壊実験 その 2 -, 日本建築学会構造 系論文集，第 74 巻，第 644 号，pp.1851-1859，2009.10

12) 島田侑子ほか 6 名:震動台実験における倒壊挙動一実大 4 層鉄骨造建物の 完全崩壊実験 その 3-, 日本建築学会構造系論文集, 第 75 巻, 第 653 号, pp.1351-1360，2010.7

13) 相良節夫ほか 3 名: システム同定, 計測自動制御学会編, コロナ社, 1987.11

14) Saito T. and Beck J.L.: Bayesian Model Selection for ARX models and its Application to Structural Health Monitoring, Earthquake Engineering \& Structural Dynamics, Vol.39, No.15, pp.1737-1759, 2010.12

15) 池田芳樹: 実大 4 層鉄骨造建物の震動台実験を利用した非線形履歴システ 么同定法の検証, 日本建築学会技術報告集, 第 17 巻, 第 34 号, pp.895-898, 2010.10

[2011 年 6 月 14 日原稿受理 2011 年 8 月 26 日採用決定］ 